\title{
THE ANALYSIS OF STUDENTS' ATTITUDE TOWARDS THE USE OF REFLECTIVE JOURNAL WRITING AS WRITING ACTIVITY
}

\author{
Yuli Herman $^{1}$, Risza Dwiputri ${ }^{2}$, Nadya Shakila Feronika ${ }^{3}$ \\ ${ }^{1}$ Universitas Mahaputra Muhammad Yamin \\ e-mail: yhman_2000@yahoo.com \\ ${ }^{2}$ Universitas Mahaputra Muhammad Yamin \\ Email: risza.dwiputri@gmail.com \\ ${ }^{3}$ Universitas Mahaputra Muhammad Yamin \\ Email: Nadyashakila1@gmail.com
}

\begin{abstract}
This study was aimed to know the attitude of students towards the use Reflective Journal Writing a writingactivity at the excellent classes of eighth grade students of SMPN 1 Solok in 2019/2020 academic year. The research method used in this study was quantitative descriptive. The population in this research was the excellent classes of eighth grade students of SMPN 1 Solok in 2019/2020 academic year. The total of population was 66 students of 2 classses The technique sample used was total sampling, where all the students in excellent classes, class VIII A and VIII B were included as the sample in the research. To get the data of the research, the researcher used questionnaire. The research design included a 5 point Likert-type questionnaire which were strongly agree (SA), Agree (A), Undecided (U), Disagree (D), and strongly Disagree (SD). In this case the researcher used 44 number of statements which based on 3 indicators of students' attitude. The indicators of attitude were divided into cognitive, emotion and behavioral aspects. The finding of this research show the final percentage of students' attitude towards reflective journal writing was $76 \%$, it was classified as in the "very good" level. It means students had a very positive attitude towards the use of reflective journal writing as writing activity.
\end{abstract}

Keywords: Students' Attitude, Reflective Journal, Writing Activity

\section{INTRODUCTION}

Students frequently face complex problems in their learning process. They need to be guided through reflective thinking. Reflective thinking is very important for students to identifying, analyzing, and solving complex problem that commonly found in classroom teaching (Spalding et.at, 2002). To enable the reflective thinking in classroom, students must be encouraged to write a journal because it imposes students to write what they think, what they know, what they feel, and why they do something, it also helps students improve their ability in 
writing skill (Yinger, 1981). Students will learn from unstructured writing to a better one. Furthermore, it motivates students to practice more and more unconsciously.

Reflective journal writing is widely used as a learning tools and it is considered in line with professional practice (Plack, et.al., 2005). There are mainly three advantages of implementing journal writing in learning process, they are: firstly, journal writing drags students in the process of learning with favorable condition. Secondly, since journal writing is related to the reflection, therefore journal writing is related to deep learning which in turn will give better understanding, and lastly it encourages metacognition skill where in metacognition students takes conscious control of learning, planning and selecting strategies, monitoring the progress of learning, correcting errors, analyze the effectiveness of learning, and changing learning strategies (Liuolienè, A., \& Metiūnienè, R, 2011).

It has been shown that journal writing gives benefits to students in learning. Stevens,et,al. (2010) in their research found that writing reflective journal has helped foreign students to release their stress, learn of tacit knowledge in academy and participate various academic activities like conference, presentation and publication.

This teaching strategy has also been implemented in Junior High School 1 in Solok Regency, West Sumatera, especially in English class. The aim of implementing this strategy is to improve the ability of the students in writing. However, when the students were interviewed in initial steps of this research, it was found that most of them think that writing is very difficult, especially in English. It is due to some barriers in English, like grammar ability, word choice, and tone of writing.

Based on some research conducted, reflective journal writing is found to be effective in increasing students' ability. Farrah (2012) found that reflective journal writing indicates the positive effects in enhancing motivation and self-confidence and improving learning in general and the writing skills in particular. Furthermore, Habibi (2017) also found that reflective journal writing can improve students' ability in developing ideas in writing ability especially in narrative text.

However, the reality found that in this school, the implementation of Reflective Journal Writing seems not significantly help the students ability in writing. Therefore, this research is aimed at seeking answers of students' attitude towards the implementation of Reflective Journal Writing in classroom teaching. 


\section{METHOD}

This research was conducted by using descriptive quantitative method. The research aimed to determine the students' attitude towards the use of Reflective Journal Writing as writing activity at excellent classes of eighth grade students of SMPN 1 Solok in 2019/2020 academic year. Prastowo (2014: 203) states that descriptive method is a research method that reveals the facts of events, objects, activities, processes, and people the way they are at the present time or period that is still possible in the memories of respondents. The population of this research was the eighth grade students at excellent classes of SMPN 1 Solok in 2019/2020 academic year. There were two classes in the excellent classes of eight grade of SMPN 1 Solok. In getting the sample of the research, the researcher used total sampling, which means the entire population were included in the research. It was because of both of the excellent classes in eighth grade in SMPN 1 Solok have made journal writing as writing activity. Total sample of the research were 66 students.

To get the data of the research, the researcher used Closed-ended questionnaire. According to Sugiyono (2009: 200), Closed-ended questionnaire is questions or statement that expects respondents to give short answer or choose one alternative answer to questions or statements that available. This questionnaire was used for getting the information about students' attitude towards the use of reflective journal writing as writing activity at the excellent classes of eighth grade students of SMPN 1 Solok in 2019/2020 academic year. The questionnaire items were made in the form of statements to which the student had to respond on five points scale by Likert Scale which were strongly agree (SA), Agree (A), Undecided (U), Disagree (D), and strongly Disagree (SD). The researcher used three components in making questionnaires they were cognitive, emotional and behavioral components. Total items of questionnaires were 44 statements. Based on Sugiyono (2013: 93) the alternative answer of question or statement of the questionnaire using Likert scale is shown in table 3.3 below :

Table 1. Alternative answer of Questionnaire

\begin{tabular}{|c|c|}
\hline Response & Score Value \\
\hline Strongly agree & 5 \\
\hline Agree & 4 \\
\hline Neutral & 3 \\
\hline
\end{tabular}




\begin{tabular}{|c|c|}
\hline Disagree & 2 \\
\hline Strongly disagree & 1 \\
\hline
\end{tabular}

Before the questionnaire was distributed to the sample of the research, the questionnaire had been validated. There were two validators who validated the questionnaire, the first is Dra. Yarmawati as one of the Lecturers in English Department of UMMY Solok and the second is Rola Jatfo S.Psi as the psychologist expert. In the validation process, the researcher did some ways. First, the researcher gave the instrument of this research to be checked by the validators. Second, the validators checked each statements of the questionnaire. Third, the validators gave some revision and suggestions on the questionnaire. After that, the researcher corrected the questionnaire based on validators' suggestion and revision. Finally, the validators filled the questionnaire validity to state that questionnaire about the use of Reflective Journal Writing as writing activity is proper to use as an instrument of this research.

In the process of collecting the data, the researcher distributed and explained the aims of the questionnaire of this research to the sample of the research. Then researcher gave the instruction to the students on how to fill the questionnaire. The researcher gave time around 50 minutes to the students in filling the questionnaire including in distributing and giving the instruction of the questionnaire. After they finish, the researcher collected the questionnaire from all the sample of the research, then the researcher calculated the percentage of students' attitude towards the use of Reflective Journal Writing as writing activity at excellent classes of eighth grade students of SMPN 1 Solok in 2019/2020 academic year.

After collecting the data, the researcher analyzed the data by using quantitative research to get the students' attitude towards the use of reflective journal writing a writing activity at excellent classes of SMPN 1 Solok in 2019/2020 academic year. The data was analyzed by calculating the percentage of students' attitude by using the formula which is suggested by Riduwan (2010: 89) as follows:

$$
\begin{aligned}
& \mathrm{P}=\frac{F}{N} \times 100 \% \\
& \mathrm{P}=\text { Percentage of the answer } \\
& \mathrm{F}=\text { Frequency } \\
& \mathrm{N}=\text { Total number of sample }
\end{aligned}
$$


After getting the total percentage of students' attitude scores, the researcher classified the percentage based on the classification. Then the researcher described the result of students' attitude toward the use of reflective journal writing as writing activity. Ahsanti (2018: 40) says that a student has a positive attitude if it has a tendency or in accordance with good criteria or category level and the other way, students have a negative attitude if it has a tendency or in accordance with not good or poor criteria or category level. The result of questionnaire is classified based on Riduwan (2010: 89) into the following interval:

Table 2. Alternative answer of Questionnaire

\begin{tabular}{|c|c|}
\hline $\begin{array}{c}\text { Interval the Frequency of } \\
\text { The Students' Attitude }\end{array}$ & $\begin{array}{c}\text { Classification Level of The } \\
\text { Students' Attitude }\end{array}$ \\
\hline $81 \%-100 \%$ & Excellent \\
\hline $61 \%-80 \%$ & Very Good \\
\hline $41 \%-60 \%$ & Good \\
\hline $21 \%-40 \%$ & Poor \\
\hline $0 \%-20 \%$ & Very poor \\
\hline
\end{tabular}

\section{FINDINGS AND DISCUSSION}

\section{Findings}

The data of the research was collected by using questionnaire at excellent classes of SMPN 1 Solok in 2019/2020 academic year. On February $5^{\text {th }}, 2020$ the Questionnaire was distributed at the Excellent Class of VIII A which consisted of 33 students and on February $6^{\text {th }}$, 2020 the Questionnaire was distributed at the Excellent Class of VIII B which also consisted of 33 students. Total of students who followed questionnaire were 66 students. The description of the result of students' attitude towards the use of reflective journal writing as writing activity can be seen in the following table:

Table 3. The Percentage of Students' Answer in Questionnaire

\begin{tabular}{|c|c|c|c|c|c|c|c|}
\hline \multirow[b]{2}{*}{ No } & \multirow[b]{2}{*}{ Aspect } & \multicolumn{5}{|c|}{ Responses } & \multirow[b]{2}{*}{ Total } \\
\hline & & $\begin{array}{c}\text { SA } \\
\text { (Strongly } \\
\text { Agree) }\end{array}$ & $\begin{array}{c}\text { A } \\
\text { (Agree) }\end{array}$ & $\begin{array}{c}\mathrm{N} \\
\text { (Neutr } \\
\text { al) }\end{array}$ & $\begin{array}{c}\text { D } \\
\text { (Disagre } \\
\text { e) }\end{array}$ & $\begin{array}{c}\text { SDA } \\
\text { (Strongly } \\
\text { Disagree) }\end{array}$ & \\
\hline
\end{tabular}




\begin{tabular}{|c|c|c|c|c|c|c|c|}
\hline \multirow[t]{2}{*}{1} & \multirow[t]{2}{*}{ Cognitive } & 1,610 & 1,776 & 693 & 102 & 8 & 4,189 \\
\hline & & $38.4 \%$ & $42.3 \%$ & $16.5 \%$ & $2.4 \%$ & $0.1 \%$ & $100 \%$ \\
\hline 2 & \multirow[t]{2}{*}{ Emotional } & 405 & 584 & 426 & 200 & 59 & 1,674 \\
\hline & & $24.1 \%$ & $34.8 \%$ & $25.4 \%$ & $11.9 \%$ & $3.5 \%$ & $100 \%$ \\
\hline \multirow[t]{2}{*}{3} & \multirow[t]{2}{*}{ Behaviour } & 1,770 & 2,304 & 993 & 114 & 2 & 5,183 \\
\hline & & $34.1 \%$ & $44.4 \%$ & $19.1 \%$ & $2.7 \%$ & $0.03 \%$ & $100 \%$ \\
\hline \multicolumn{2}{|c|}{ Total Scores } & 3,785 & 4,664 & 2,112 & 416 & 69 & 11,046 \\
\hline \multicolumn{2}{|c|}{ Percentage } & $34.2 \%$ & $42.2 \%$ & $19.1 \%$ & $3.7 \%$ & $0.6 \%$ & $100 \%$ \\
\hline \multicolumn{2}{|c|}{ Total frequency } & \multicolumn{6}{|c|}{14,520} \\
\hline \multicolumn{2}{|c|}{ Total Percentage } & \multicolumn{6}{|c|}{$76 \%$} \\
\hline
\end{tabular}

Based on the table above, it can be described that from 66 students and 44 questionnaire of the three indicators, which were cognitive, emotional, and behavioural aspect, the total of students' score was 11,046 . The students' total score in the category of strongly agree was 3,785 (34.2\%). Then, in category of agree, the score was 4664 (42.2\%). In the category of neutral, the score was $2,112(19.1 \%)$. In the category of disagree, the score was $416(3.7 \%)$ and $69(0.6 \%)$ in the category of strongly disagree.

It can be concluded that from the categories of the strongly agree and agree which got the percentage $34.2 \%$ and $42.2 \%$, so around $76.4 \%$ of students' answer was positive based on the statements given. In fact, around $19.1 \%$ of the students' answer was neutral. Then, from the categories of disagree and totally disagree which got the percentage $3.7 \%$ and $0.6 \%$, so around $4.3 \%$ of students' answer was negative based on the statements given.

The final percentage was $\mathbf{7 6 \%}$, it was classified as very good. In addition, the percentage of students' highest answer was from the option of strongly agree and agree. It means that the students had positive attitude towards the use of reflective journal writing as writing activity. It can be said that, based some indicators, which were cognitive, emotional and behavioral aspects, most students agreed that reflective journal writing gave some good impacts for them especially in writing.

\section{Discussion}

Although Reflective Journal writing seems not significantly improve the students' writing ability, the finding of this research found that students welcome to this teaching strategy. In every aspect of reflective journal writing shows the positive attitude of the students. From this 
fact, it can be argue that the difficulties in writing will not influence the students' positive attitude toward this strategy. Therefore, it needs more study to find out answers of this "irrelevant" happen.

\section{CONCLUSION AND SUGGESTION}

From the research findings, it can be concluded that the students had positive attitude toward using reflective journal writing as writing activity, and it classified as very good. The following items were the result of students' attitude towards the use of reflective journal writing as writing activity based on three indicators, which were cognitive, emotional and behavioral aspect. It can be concluded as follow :

1. The final percentage of students' attitude based on cognitive aspect towards the use of reflective journal writing as writing activity at the excellent classes of eighth grade students of SMPN 1 Solok in 2019/2020 academic year was $79.3 \%$ which could be classified as very good. It means that the students had very good attitude towards the use of reflective journal writing as writing activity on cognitive aspect. Most students agreed that they had better understanding in connecting, creating, checking, and applying their knowledge in writing by using Reflective Journal.

2. The final percentage of students' attitude based on emotional aspect towards the use of reflective journal writing as writing activity at the excellent classes of eighth grade students of SMPN 1 Solok in 2019/2020 academic year was $63.4 \%$ which could be classified as very good. It means that the students had very good attitude towards the use of reflective journal writing as writing activity on emotional aspect. Most students liked and enjoyed using reflective journal writing as writing activity.

3. The final percentage of students' attitude based on behavioral aspect towards the use reflective journal writing as writing activity at the excellent classes of eighth grade students of SMPN 1 Solok in 2019/2020 academic year was $78.5 \%$ which could be classified as very good level. It means that the students had positive attitude towards the use of reflective journal writing as writing activity on behavioral aspect. Most students agreed that they were more interested, active and hard-working to learn more in writing activity through using reflective journal writing. 
Based on the conclusion above, the researcher proposes the following suggestions. They are as follow:

1. For the teacher, the teacher should encourage his/her students to use reflective journal writing due to its many benefits, so the students will become more motivated to use it. Hopefully, the researcher also suggests that the teacher do more correction in students' writing through their Reflective Journal.

2. For the students, it is hoped that the students have more effort to improve their ability in writing activity. It is hoped that the students can be more active, creative and motivate themselves and others related to do any writing task, they can used some techniques, such as using reflective journal writing or others.

3. For the next researcher, it is hoped that the next researcher can continue in improving this research in the future. It is suggested to other researchers to carry out further studies related on students' attitude toward the use of reflective journal writing as writing activity, so that it can give more information.

\section{REFERENCES}

Ahsanti, N. (2018). Students' Attitude towards English for Business. Unpublished Thesis Semarang: Walisongo State Islamic University Semarang.

Farrah, M. (2012). Reflective journal writing as an effective technique in the writing process.

Habibi, F. (2017). The Effect of Reflective Journal Writing on Students' Writing Ability in Narrative Text. Unpublished Thesis. Jakarta: Syarif Hidayatullah State Islamic University.

Langat, A. C. (2015). Students' attitudes and their effects on learning and achievement in Mathematics: A Case study of public secondary schools in Kiambu County, Kenya. Unpublished a Reserch Project, submitted in partial fulfilment of the requirements for the Degree of Master of Education of Kenyatta University. Available online also at: https://ir-library. ku. ac. ke/bitstream/handle/123456789/10911/Students [accessed in Manila, the Philippines: June 22, 2018$].$

Liuolienè, A., \& Metiūnienè, R. (2011). Students' learning through reflective journaling. Coactivity: Philology, Educology/Santalka: Filologija, Edukologija, 17(4), 3237.

Plack, M. M., Driscoll, M., Blissett, S., McKenna, R., \& Plack, T. P. (2005). A method for assessing reflective journal writing. Journal of allied health, 34(4), 199-208.

Prastowo, A. (2014). Metode Penelitian Kualitatif dalam Perspektif Rancangan Penelitian. 
Jogjakarta: Ar-Ruz Media.

Riduwan. (2010). Skala Pengukuran Variabel-Variable Penelitian. Bandung: Alfabeta.

Spalding, E., Wilson, A., \& Mewborn, D. (2002). Demystifying reflection: A study of pedagogical strategies that encourage reflective journal writing. Teachers college record, 104(7), 1393-1421.

Stevens, D. D., Emil, S., \& Yamashita, M. (2010). Mentoring through reflective journal writing: A qualitative study by a mentor/professor and two international graduate students. Reflective Practice, 11(3), 347-367.

Sugiyono. (2009). Metode Penelitian Kuantitatif, Kualitatif dan R\&D. Bandung : Alfabeta.

Sugiyono. (2013). Metode Penelitian Kuantitatif, Kualitatif dan R\&D. Bandung: CV Alfabeta

Yinger, R. J., \& Clark, C. M. (1981). Reflective journal writing: Theory and practice. 